\title{
Responses of hardwood regeneration to fire in mesic forest openings. II. Leaf gas exchange, nitrogen concentration, and water status
}

\author{
Eric L. Kruger and Peter B. Reich
}

\begin{abstract}
The physiological responses of tree regeneration to fire were studied in openings in a mesic hardwood forest. Gas exchange, nitrogen concentration, and water potential were monitored on foliage of burned and nonburned regeneration of northern red oak (Quercus rubra L.), white ash (Fraxinus americana L.), and sugar maple (Acer saccharum Marsh.) following spring fires in 1989 and 1990. Fire led to a stimulation of light-saturated photosynthesis in foliage of resprouting plants, but the effect varied in magnitude among species. On average, photosynthesis of post-fire maple was $42 \%$ higher than that on nonburned plots, with corresponding increases occurring in stomatal conductance and leaf $\mathrm{N}$ concentration. In general, fire had a marginal effect on leaf properties of oak and ash. In 1990, the ratio of root area to leaf area and the water potential of sunlit foliage were significantly higher on burned than nonburned plots for maple, but not for oak or ash, paralleling trends in photosynthesis. There was little evidence of a treatment difference in soil moisture or nitrogen availability, and it appeared that fire-induced stimulations in photosynthesis were mediated primarily by changes in intrinsic (e.g., root area/leaf area ratio) as opposed to extrinsic (e.g., soil moisture) factors governing resource availability to the canopy of post-fire sprouts.
\end{abstract}

\begin{abstract}
Résumé : Les réactions physiologiques au passage du feu de la régénération forestière installée dans des trouées d'une forêt de feuillus mésique ont été étudiées. À la suite de brûlages printaniers réalisés en 1989 et 1990, on a mesuré les échanges gazeux, la concentration en azote foliaire ainsi que le potentiel hydrique de la régénération de chêne rouge (Quercus rubra L.), de frêne d'Amérique (Fraxinus americana L.) et d'érable à sucre (Acer saccharum Marsh.) dans des parcelles brûlées et non brûlées. Le feu a entraîné une stimulation de la photosynthèse en condition de lumière saturée dans le feuillage des rejets de feuillus mais les effets variaient en importance selon les espèces. En moyenne, la photosynthèse de l'érable était de $42 \%$ plus élevée dans les parcelles brûlées que dans les parcelles non brûlées, accompagnée d'une augmentation correspondante de la conductivité stomatique et de la concentration en $\mathrm{N}$ foliaire. En général, le feu a exercé un effet marginal sur les propriétés foliaires du chêne et du frêne. En 1990, le rapport de la surface racinaire sur la surface foliaire et le potentiel hydrique des feuilles exposées à la lumière étaient significativement plus élevés dans les parcelles brûlées que dans les parcelles non brûlées pour l'érable mais non pour le chêne ou le frêne, imitant de la sorte les tendances observées à l'égard de la photosynthèse. Il n'est pas évident qu'il existe une différence entre les traitements au sujet de la disponibilité de l'azote ou de l'humidité du sol. Il semble que la stimulation de la photosynthèse induite par le feu provienne de changements dans les facteurs intrinsèques (p. ex. le rapport surface racinaire sur surface foliaire), par opposition aux facteurs extrinsèques (p. ex. humidité du sol), régissant la disponibilité des ressources dans le couvert des rejets qui émergent après feu.

[Traduit par la Rédaction]
\end{abstract}

\section{Introduction}

Fire often dramatically alters the structure and composition of woody plant communities by killing fire-sensitive individuals and facilitating rapid invasions by disturbance-adapted species (Ahlgren 1974; Bond and van Wilgen 1996). However, particularly when the extent of mortality is limited, the most enduring impacts of fire on community dynamics may be those which influence competitive interactions among surviving plants (Perala 1974; Busch and Smith 1993). Changes in competitive status may result from differential fire effects on plant size (e.g., live stem height) or growth rate, the latter being

Received July 31, 1996. Accepted July 7, 1997.

E.L. Kruger. ${ }^{1}$ Department of Forestry, University of Wisconsin-Madison, 120 Russell Labs, 1630 Linden Avenue, Madison, WI 53706, U.S.A.

P.B. Reich. Department of Forest Resources, University of Minnesota, St. Paul, MN 55108, U.S.A.

1 Author to whom all correspondence should be addressed. mediated by modifications of microenvironment, resource availability, or any of a suite of plant physiological, morphological, and allocational attributes.

A notable example of such a modification has been observed in post-fire woody resprouts, which often have higher light-saturated rates of leaf photosynthesis than individuals in nonburned areas (Oechel and Hastings 1983; DeSouza et al. 1986; Reich et al. 1990; Fleck et al. 1995). Several factors may underlie this stimulation in leaf function, including increased foliar concentrations of $\mathrm{N}$ or other nutrients resulting from post-fire increases in soil nutrient availability (Oechel and Hastings 1983; Reich et al. 1990). Alternatively, leaf gas exchange may be responsive to improvements in leaf nutrient or water status, or to increased foliar levels of root-derived hormones, resulting from an increase in post-fire root/shoot ratio brought about by the destruction of aboveground tissues (Wareing et al. 1968; Meinzer and Grantz 1990; Reich et al. 1990; Kruger and Reich 1993a, 1993b). Another possible consequence of fire damage is a decrease in source/sink ratio, which in turn can lead to a stimulation of photosynthetic capacity (Neales and Incoll 1968; Tschaplinski and Blake 1989; 
Syvertsen 1994). Regardless of its cause, a post-fire enhancement of leaf photosynthesis may play a critical role in the recovery and competitive status of woody survivors.

In a study of post-fire community dynamics in a mesic hardwood forest (Kruger and Reich 1997a), spring burning had little effect on the survival and height growth of northern red oak (Quercus rubra L.) regeneration, but it decreased the density and growth rate of key hardwood competitors. In an effort to elucidate the causes underlying species differences in postfire growth, we monitored leaf gas exchange in burned and nonburned regeneration of northern red oak, white ash (Fraxinus americana L.), and sugar maple (Acer saccharum Marsh.). In this paper we present data on the responses of leaf gas exchange to fire, and also explore the possible factors underlying these responses, including leaf $\mathrm{N}$ and water status, the balance between root and leaf area, and soil moisture and $\mathrm{N}$ availability. In a companion paper (Kruger and Reich 1997b), these data are used to help explain the differential effects of fire on whole-plant growth of the three species

\section{Materials and methods}

\section{Study site and experimental approach}

In the spring of 1989 , two $200-\mathrm{m}^{2}$ plots were established in each of four newly created 0.5 -ha openings (blocks) in a mesic hardwood forest in southwestern Wisconsin. A pair of openings was located on each of two north-facing hillsides. One randomly chosen plot in each opening was burned in early May of both 1989 and 1990, and the other was left as a nonburned control. Leaf phenology, gas exchange, nitrogen concentration, and water potential were monitored on both extant (less than $2 \mathrm{~m}$ in height) and planted regeneration of red oak, white ash, and sugar maple on burn and control plots during the growing seasons of 1989 and 1990. Individuals of two different origins were planted on all plots in April 1989. Bare-root seedlings of each species (1-year-old oak, and 2-year-old maple and ash) were obtained from the Wilson State Nursery, Boscobel, Wisconsin. In addition, forest-grown regeneration-stage individuals of the three species were transplanted onto the plots from adjacent mesic understories. The forest population, composed of seedling sprouts as well as seedlings, was included to determine whether differences in treatment responses between extant and planted regeneration were related to prior cultural conditions as opposed to establishment stress. Fifteen nursery seedlings and 10 forest-grown individuals per species were planted on each plot.

Precipitation during the growing season (May-September) of 1989 was $150 \mathrm{~mm}$ less than the 30 -year average for that period $(490 \mathrm{~mm})$, owing largely to a lack of rainfall in May and June (United States Department of Commerce 1989). Precipitation during the 1990 growing season was $170 \mathrm{~mm}$ higher than average, with abundant rainfall occurring in every month except September (United States Department of Commerce 1990). Additional information regarding the study site, experimental design, and treatments is provided in a companion paper (Kruger and Reich 1997a).

\section{Measurement of leaf gas exchange}

On clear mornings during the 1989 and 1990 growing seasons, net photosynthesis $\left(A_{\text {area }}\right)$, hereafter referred to as photosynthesis, and stomatal conductance $\left(g_{\mathrm{s}}\right)$ were measured on sunlit leaves of randomly chosen individuals of the three species on burn and control plots. On control plots in 1990, gas exchange was also measured in August on leaves of basal sprouts from individuals of all three species that were coppiced $2 \mathrm{~cm}$ above the soil surface in early May of that year ( 3 days after burning). The purpose of this manipulation was to help isolate the factors underlying fire effects on leaf function by comparing leaf behavior after fire with that resulting from top kill alone.

Leaf gas exchange was measured with an LCA-2 portable infrared gas analyzer and a Parkinson broadleaf chamber (Analytical Development Company, Hoddesdon, U.K.), operated as an open system. Gas exchange parameters were calculated with the equations of von Caemmerer and Farquhar (1981), except that the effect of water vapor dilution on infrared gas analyzer $\mathrm{CO}_{2}$ measurements was determined empirically (Bunce and Ward 1985). For all gas exchange data reported here, incident photosynthetic photon flux density (PPFD) was greater than $600 \mu \mathrm{mol} \cdot \mathrm{m}^{-2} \cdot \mathrm{s}^{-1}$, which was typically sufficient to saturate photosynthesis in all three species (E.L. Kruger, unpublished data). During measurements, the gas exchange system was periodically allowed to cool in the shade, and leaf temperature and leafto-air vapor pressure gradient in the cuvette ranged from 23 to $31^{\circ} \mathrm{C}$ and 0.7 to $2.2 \mathrm{kPa}$, respectively. Measurements were made with ambient air, and $\mathrm{CO}_{2}$ concentrations averaged $332 \mu \mathrm{L} \cdot \mathrm{L}^{-1}$ (range 316-352 $\left.\mu \mathrm{L} \cdot \mathrm{L}^{-1}\right)$.

Throughout the study gas exchange was measured on similar numbers of extant and planted regeneration, and they did not differ significantly $(p>0.10)$ in $A_{\text {area }}$ or $g_{\mathrm{s}}$ in either year; therefore data from the two regeneration types were pooled in all analyses. Typically, one first-flush leaf from four to six individuals per species was measured on each plot in two blocks during a given morning. In 1989, the majority of extant and planted regeneration flushed only once, regardless of species or treatment, and thus only first-flush leaves were measured. In 1990, the majority of maple and oak, as well as some of the ash, produced more than one leaf flush on control plots, and this was also the case for oak on burn plots. When fully expanded (late July), this younger foliage was measured in addition to the first flush. In the case of oak and ash, there were no significant differences $(p>$ 0.10 ) between gas exchange rates of first-flush and younger leaves, and thus only data from first-flush leaves were reported in the results. A full assessment of all eight plots, represented as a single date in the results, actually required two consecutive days. Moreover, certain measurement "dates" (in June 1989 and September 1990) included data from only two of the four blocks. On these occasions, one of the two blocks on each of the two hillsides was randomly selected for measurement.

\section{Analysis of carbon isotope ratios in maple stem tissue}

To help elucidate the causes for treatment differences in leaf gas exchange, current-year stem growth was harvested from maple regeneration on all plots in the fall of 1990 , dried to a constant mass at $70^{\circ} \mathrm{C}$, ground, pooled within plot, and analyzed for carbon isotope ratio $\left(R={ }^{13} \mathrm{C} /{ }^{12} \mathrm{C}\right)$ using a Finnigan Delta $\mathrm{E}$ mass spectrometer (Finnigan MAT, Breman, Germany). Data were expressed as ${ }^{13} \mathrm{C}$ discrimination $\left(\delta^{13} \mathrm{C}, \%\right.$, relative to the Pee Dee Belemnite standard, where $\left(\delta^{13} \mathrm{C}, \%\right)=$ $\left(R_{\text {sample }} / R_{\text {standard }}-1\right) \times 1000$. Reproducibility was $0.1 \%$ based on repeated analysis of a well-homogenized plant tissue sample. Resource constraints limited the analysis to one species, and maple was chosen because it exhibited the largest leaf responses to treatment. New stem tissues were used to ensure that the carbon being analyzed was assimilated (presumably by mature source leaves) primarily in 1990.

\section{Measures of leaf and soil nitrogen and water status}

Following gas exchange measurements, leaves were harvested, measured for area (LI-COR 3100 leaf area meter, LI-COR Inc., Lincoln, Nebr.), dried to a constant mass at $70^{\circ} \mathrm{C}$, weighed, ground, and submitted to the University of Wisconsin Plant and Soil Analysis Lab for determination of $\mathrm{N}$ concentration by micro Kjeldahl methods (Schulte et al. 1987). For each measurement date, leaves collected from a given species were pooled within plots for this analysis.

Net rates of soil N mineralization were estimated in both 1989 and 1990 with in situ, buried-bag soil incubations (Eno 1960; Gower and Son 1992). Five soil cores, $5 \mathrm{~cm}$ diameter $\times 20 \mathrm{~cm}$ depth, were taken from randomly chosen locations on each plot and placed in separate 
Table 1. Growing season (June through September) means for leaf properties in 1989 and 1990

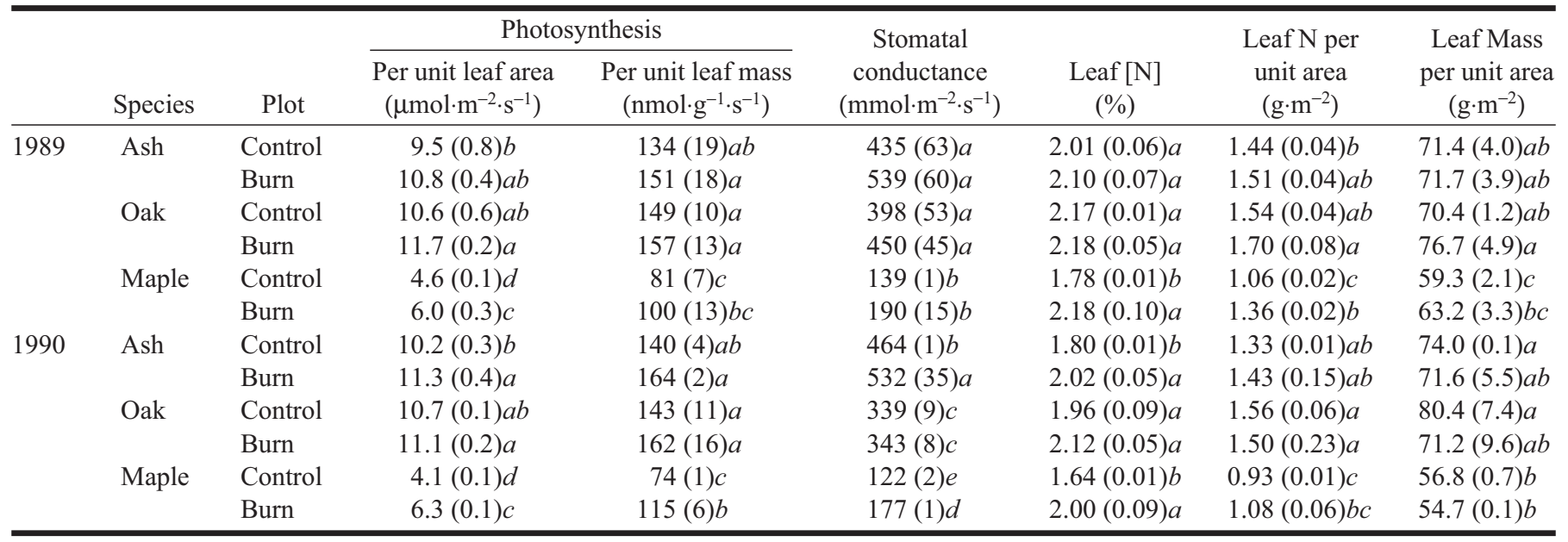

Note: For reasons discussed in the Materials and methods, means (with standard errors) were calculated using growing season averages from each of the two hillsides $(n=2$ per treatment $\times$ species combination). Within years and columns, means without common letters are significantly different at $p \leq 0.05$.

polyethylene bags ( $0.04 \mathrm{~mm}$ wall thickness). The bags were sealed and reinserted into the soil at the same location. Adjacent to each location another core of identical dimensions was removed, stored at $3^{\circ} \mathrm{C}$ (for less than $24 \mathrm{~h}$ ), and processed as outlined below. In 1989, buried bags, which were placed on the plots and also in adjacent understories, were installed on May 15 and retrieved on November 15. In 1990, bags were installed (in plots only) on May 1, June 23, and October 1 , and incubation periods ranged from 4 to 7 weeks. Harvested soil cores were stored at $3{ }^{\circ} \mathrm{C}$ (for less than $24 \mathrm{~h}$ ) and then homogenized, after which a $15 \mathrm{~g}$ (fresh mass) sample from each was extracted in $100 \mathrm{~mL}$ of $2 \mathrm{M} \mathrm{KCl}$ for $24 \mathrm{~h}$. Extracts were then analyzed colorimetrically for $\mathrm{NO}_{3}{ }^{-}$and $\mathrm{NH}_{4}{ }^{+}$concentrations with a Lachat continuous flow ion analyzer (Lachat Inc. 1986; 1987). Additional soil samples were weighed, dried, and reweighed to determine the dry mass of extracted soil. The net rate of $\mathrm{N}$ mineralization was calculated as the change in soil inorganic $[\mathrm{N}]\left(\left[\mathrm{NO}_{3}{ }^{-}\right]+\left[\mathrm{NH}_{4}^{+}\right]\right)$per month of incubation $\left(\mu \mathrm{g} \cdot \mathrm{g}^{-1} \cdot \mathrm{month}^{-1}\right)$.

Five soil cores $20 \mathrm{~cm}$ in depth were also collected from each plot and measured for moisture content every 24-35 days in both 1989 and 1990. Cores were weighed fresh, dried to a constant mass at $70^{\circ} \mathrm{C}$, and reweighed. Soil moisture content $(\%)$ was calculated as [(soil fresh mass - soil dry mass $/$ soil dry mass] $\times 100$. Soil water potential was also estimated once in each month of the growing season with measures of predawn leaf water potential (Ritchie and Hinckley 1975) using a pressure chamber (PMS Instruments, Corvallis, Oreg.). In addition, on the mornings of July 1 and August 25, 1990, gas exchange measures were immediately followed by pressure chamber determinations of sunlit leaf water potential ( $\Psi, \mathrm{MPa})$.

\section{Measures of root area/leaf area ratios}

With the exception of ash on burn plots, seedlings measured for sunlit leaf $\Psi$ on July 1 and August 25, 1990, were harvested soon afterward to determine the balance between root and leaf area. The poor survival of ash on burn plots (Kruger and Reich 1997a) precluded its involvement in this analysis. Plant leaf area was determined as described previously. The total projected area of a root system was estimated using species-specific relationships between projected root area $\left(\mathrm{cm}^{2}\right)$ and root dry mass. These were based on a sample of plants (9-12 per species), harvested on or near the study plots, that comprised a wide range of root system sizes (e.g., 2 to $22 \mathrm{~g}$ dry mass for ash). Projected root areas were measured with a digital scanning leaf area meter (Decagon Devices, Logan, Utah). We observed the following relationships between root area and mass: for ash, root area $=\exp [4.0-$ $0.61 \ln ($ root mass $)], r^{2}=0.92, p=0.0002$; for maple, root area $=$ $\exp [3.4-0.60 \ln$ (root mass) $], r^{2}=0.80, p=0.0005$; and for oak, root area $=\exp [2.6-0.62 \ln ($ root mass $)], r^{2}=0.97, p<0.0001$.

\section{Statistical analyses}

The effects of treatment, species, and their interaction were examined with analysis of variance (ANOVA) using the general linear models procedure (PROC GLM) in SAS (SAS Institute Inc. 1988). The study was set up as a split-plot design in a randomized complete block arrangement, treating plots as whole units and species as subunits. When the effect of blocking was not significant $(p>0.10)$ the data were analyzed as if the design were a split plot in a completely randomized arrangement. Relationships among continuous variables were analyzed with linear regression (PROC GLM). Unless specified otherwise, regressions and differences among means were significant if $p \leq 0.05$. The effects of coppicing in 1990 were analyzed by treating the coppiced population as a third whole unit. In examining relationships among the whole-unit mean residuals (departures of whole-unit means from grand mean in each block) for various leaf parameters, we found no evidence to reject the assumption of independence between coppiced and noncoppiced treatments.

Homogeneity of variance was tested with Levene's method (Milliken and Johnson 1989); when the assumption of homogeneity was rejected, the data were transformed (e.g., with natural logarithm) prior to ANOVA. Fisher's protected LSD was used to identify significant differences among species $\times$ treatment means. In accordance with the split-plot design, different LSDs were calculated for mean comparisons within and across treatments. The derivation of within-treatment LSDs was based on subunit error, while across-treatment LSDs were calculated based on a combination of subunit and whole-unit error (Milliken and Johnson 1989). In the case of root/leaf area data one treatment $\times$ species combination was missing, and therefore error terms and test statistics were calculated using the methods recommended by Milliken and Johnson (1989) for missing subunits in a split-plot design.

Growing season means for leaf properties (Table 1) were generated from data collected in June through September. Because leaf properties were not assessed in all plots on every measurement date, we used hillside rather than plot averages as experimental units $(n=2)$ for each species $\times$ treatment combination. The validity of this strategy rested on the assumption that either of the two openings (blocks) on a hillside was representative of the hillside as a whole, and this was supported by the absence of a significant effect of block or block $\times$ treatment interaction (tested with subsample error) on any parameter. Seasonal means for a given parameter were derived by calculating the 
Fig. 1. Seasonal dynamics in net photosynthesis, stomatal conductance, and N per unit leaf area for regeneration of ash, oak, and maple on burn $(\bigcirc)$ and control $(\bigcirc)$ plots in 1989 and 1990. For maple, data are also shown for the second leaf flush on control plots $(\triangle)$. Asterisks indicate significant differences $(p \leq 0.05)$ between treatment means on a given date.

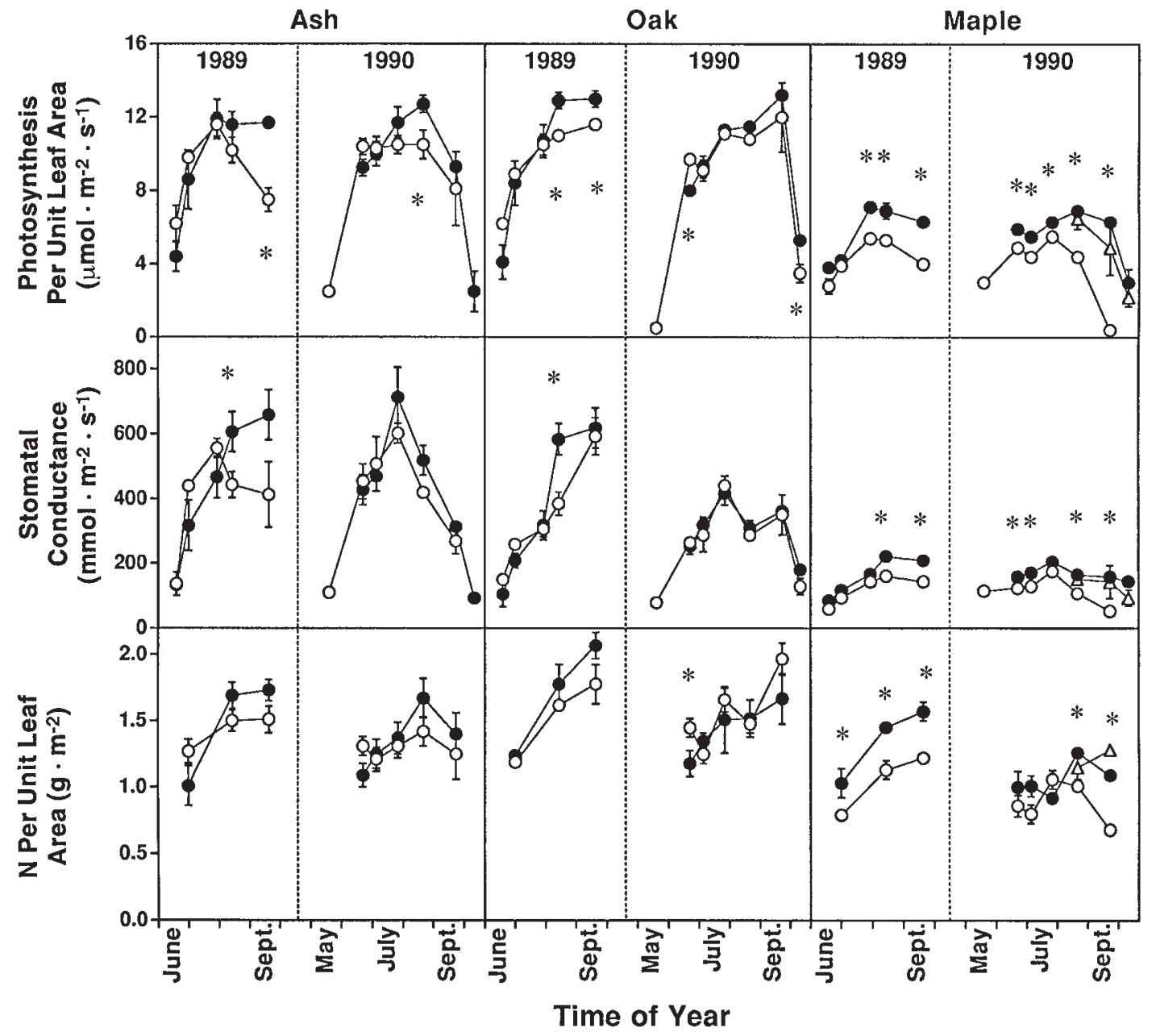

average of each pair of consecutive measurements during a growing season, and then averaging these values after weighting each according to the time interval that it represented.

\section{Results}

\section{Leaf phenology}

In both 1989 and 1990, the apical buds of tree regeneration were swelling or beginning to open at the time of burning in early May. Among the three species, bud expansion was most advanced in maple at that time, while ash and oak lagged several days behind. Burning girdled nearly all woody stems, and basal sprouts appeared 10 to 20 days after each fire. For all species, expansion of the first leaf flush was completed by mid-June on control plots. Because leaves expanded more rapidly on burn than control plots, fire delayed full leaf expansion by at most 10 days. Coppicing on control plots produced a similar delay in development. Maple leaves were the first to reach full expansion in all treatments. On control plots in 1989, leaf senescence occurred in mid-October for oak and mid-September for maple and ash. Fire delayed senescence by several days for all three species in that year. In 1990, ash and maple leaves senesced in late September on control plots and 15 to 20 days later on burn plots. However, on control plots young secondflush leaves of maple, which developed in July and represented less than $20 \%$ of total canopy area, persisted for 15 to 20 days longer than the remainder of the canopy. Oak foliage senesced in late October in both treatments in 1990.

\section{Leaf gas exchange and $N$ concentration}

Seasonal patterns of leaf gas exchange varied among species and to a lesser extent between treatments (Fig. 1). On control plots, seasonal maxima and subsequent declines in $A_{\text {area }}$ and $g_{\mathrm{s}}$ tended to occur earlier for ash and maple than for oak. Burning did not affect seasonal patterns for oak, but it delayed the peak in $g_{\mathrm{s}}$ for ash in 1989 and $A_{\text {area }}$ for ash and maple in 1990. In the case of growing season means, $A_{\text {area }}$ and $g_{\mathrm{s}}$ of oak and ash more than doubled those of maple on control plots in both years, with consistent but smaller differences occurring in massbased photosynthesis $\left(A_{\text {mass }}\right)$ (Table 1$)$.

Among the three species, maple exhibited the most pronounced and consistent leaf responses to fire. On several measurement dates during the two years, the $A_{\text {area }}$ and $g_{\mathrm{s}}$ of maple were at least $30 \%$ higher $(p \leq 0.05)$ on burn plots than on controls (Fig. 1). One exception to this occurred in the latter part of 1990, when gas exchange rates of second-flush leaves 
Fig. 2. Comparisons of net photosynthesis, stomatal conductance, and $\mathrm{N}$ per unit leaf area for coppiced and noncoppiced individuals on control plots, as well as post-fire sprouts on burn plots. Columns represent treatment $\times$ species means (and their standard errors) of leaf properties measured on or about August 25, 1990. Fisher's least significant differences (LSD, $p=0.05$ ) are provided for comparing means within $\left(\mathrm{LSD}_{\mathrm{WT}}\right)$ and across $\left(\mathrm{LSD}_{\mathrm{AT}}\right)$ treatments.

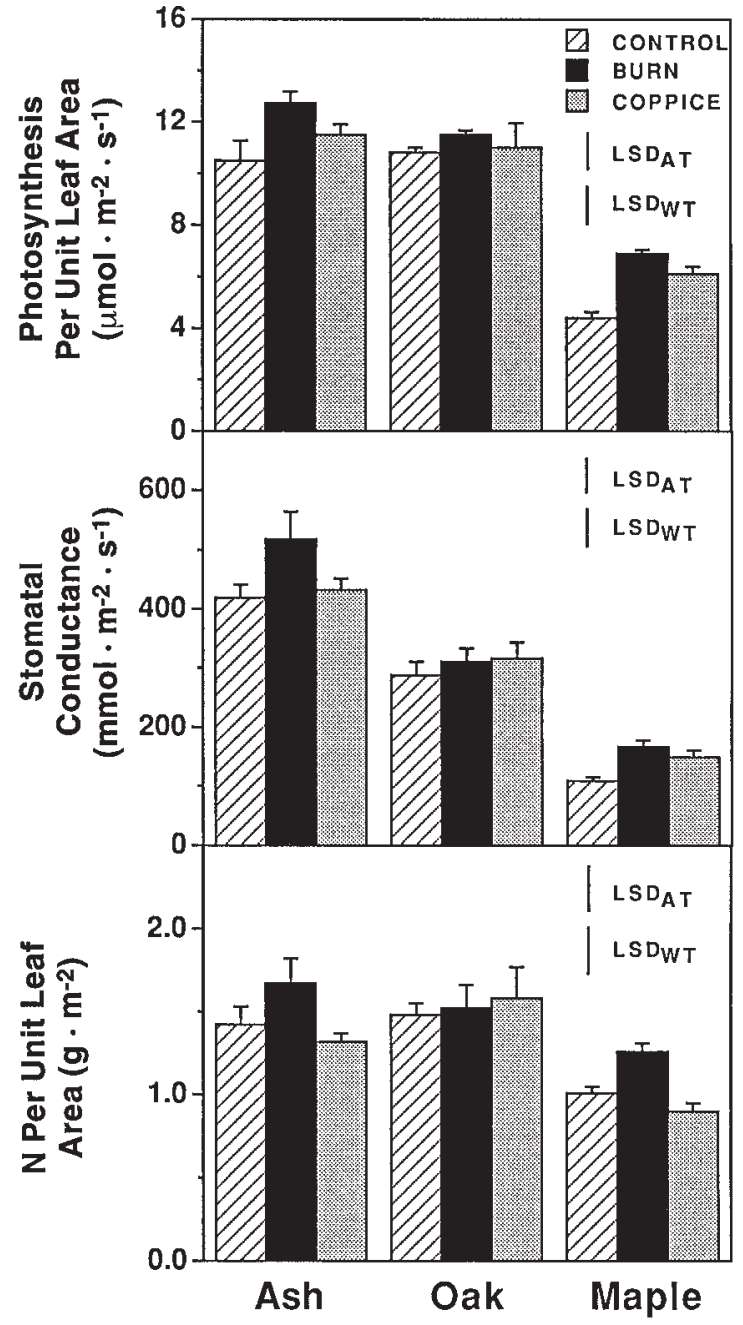

on control plots resembled burn plot values (Fig. 1). Across years, seasonal means for $A_{\text {area }}, A_{\text {mass }}$ and $g_{\mathrm{s}}$ on burn plots were $39-42 \%$ higher than those on controls for maple, and $10-15 \%$ higher for ash (Table 1). For both species, significant treatment differences in seasonal means were more common in 1990 than in 1989. The relatively modest treatment differences in seasonal gas exchange were never significant for oak. However, fire did lead to a significant increase in seasonal maximum $A_{\text {area }}$ for oak in 1989 (Fig. 1). For maple, $A_{\text {area }}$ and $g_{\mathrm{s}}$ of coppiced plants exceeded those of noncoppiced individuals on control plots in 1990. On August 25, gas exchange rates of coppiced maples resembled those on burn plots and were $30-40 \%$ higher than rates of intact individuals $(p \leq 0.05$ for $A_{\text {area }}$ and $p=0.06$ for $g_{\mathrm{s}}$ ) (Fig. 2). Coppicing did not have a significant effect on leaf gas exchange in oak or ash.

Seasonal patterns as well as species and treatment differences in $\mathrm{N}$ per unit leaf area (LNA, $\mathrm{g} \cdot \mathrm{m}^{-2}$ ) generally paralleled those in $A_{\text {area }}$ (Fig. 1 and Table 1). On control plots, oak had the highest seasonal averages for LNA, followed by ash and then maple (Table 1). As with photosynthesis, fire had a larger effect on the nitrogen status of maple than it did on that of oak or ash. Seasonal averages for maple LNA and leaf [N] were $16-28 \%$ higher $(p \leq 0.05)$ on burn than control plots, whereas, except for ash leaf [N] in 1990, they did not differ significantly between treatments for ash or oak. There was no significant treatment effect on the seasonal average of leaf mass per unit area (LMA, $\mathrm{g} \cdot \mathrm{m}^{-2}$ ) for any species in either year (Table 1 ).

\section{Relationships between photosynthesis and stomatal conductance or leaf $\mathbf{N}$}

For each of the three species, $A_{\text {area }}$ was strongly and positively correlated with $\ln g_{\mathrm{s}}$. Neither the intercept nor the slope of this relationship differed significantly between treatments, and therefore data from all treatments and years were used to derive a single regression for a given species (Table 2). Correspondingly, the $\delta^{13} \mathrm{C}$ of current-year stem growth in $1990 \mathrm{did}$ not differ between treatments for maple; the mean $\delta^{13} \mathrm{C}$ on burn and control plots was -25.4 and $-25.6 \%$, respectively (treatment $n=4, \mathrm{SE}<0.2 \%$ ). Comparisons of $A_{\text {area }}$ versus $\ln g_{\mathrm{s}}$ across species revealed that, at a given $g_{\mathrm{s}}$, oak had a higher $A_{\text {area }}$ than ash or maple $(p \leq 0.05)$. $A_{\text {area }}$ was also positively but less strongly related to LNA (Table 2 ). In the cases of ash and oak, neither the slope nor the intercept of this relationship differed significantly between treatments, and for each species a single regression was derived with data from both treatments and years. At a particular LNA both oak and ash had a higher $A_{\text {area }}$ than maple $(p \leq 0.05)$, regardless of treatment. Within maple, the $A_{\text {area }}$ of post-fire sprouts was significantly higher than that of controls at a given LNA.

\section{Plant water status and the balance between root and leaf area}

As with $g_{\mathrm{s}}$, the water potential $(\Psi)$ of sunlit foliage, measured in the mornings of July 1 and August 25, 1990, was significantly higher (less negative) on burn than control plots for maple (Fig. 2), indicating an increased availability of water to post-fire maple foliage. No significant treatment difference was observed for oak or ash. Correspondingly, the ratio of projected root area to leaf area was $80 \%$ higher $(p \leq 0.05)$ on burn plots for maple on those dates (Fig. 3), whereas treatments did not differ significantly in the case of oak (ash was not measured on burn plots).

\section{Soil moisture and $\mathbf{N}$ availability}

Soil moisture content remained near field capacity (ca. 45\%) on both burn and control plots during the latter part of the growing season in 1989 and throughout 1990 (data not shown). Soil moisture declined during a period of low rainfall in June and early July of 1989 . Average moisture content was $28 \%$ by the end of this period, at which time predawn leaf $\Psi$ on burn and control plots averaged $-0.3,-0.1$, and $-0.5 \mathrm{MPa}$ for ash, oak, and maple, respectively. Otherwise, daily averages for predawn $\Psi$ remained above $-0.3 \mathrm{MPa}$ for all species in both years. Treatments never differed significantly in soil moisture or predawn $\Psi$, and the same held true for soil $\mathrm{N}$ mineralization (Table 3). In 1989, mineralization rates were relatively low, and net $\mathrm{N}$ immobilization was observed in understories adjacent to the plots. Although rates appeared to be higher in 1990, 
Fig. 3. Water potential of sunlit foliage, and the ratio of projected root area to leaf area for regeneration of ash, oak, and maple on July 1 and August 25, 1990. Columns represent treatment $\times$ species means (and their standard errors). For a given species and treatment, leaf properties did not differ significantly between dates, and therefore data from both dates were pooled within plots $(n=4)$. Data on root and leaf areas were not obtained for ash on burn plots. Fisher's least significant differences (LSD, $p=0.05$ ) are provided for comparing means within $\left(\mathrm{LSD}_{\mathrm{WT}}\right)$ and across $\left(\mathrm{LSD}_{\mathrm{AT}}\right)$ treatments.

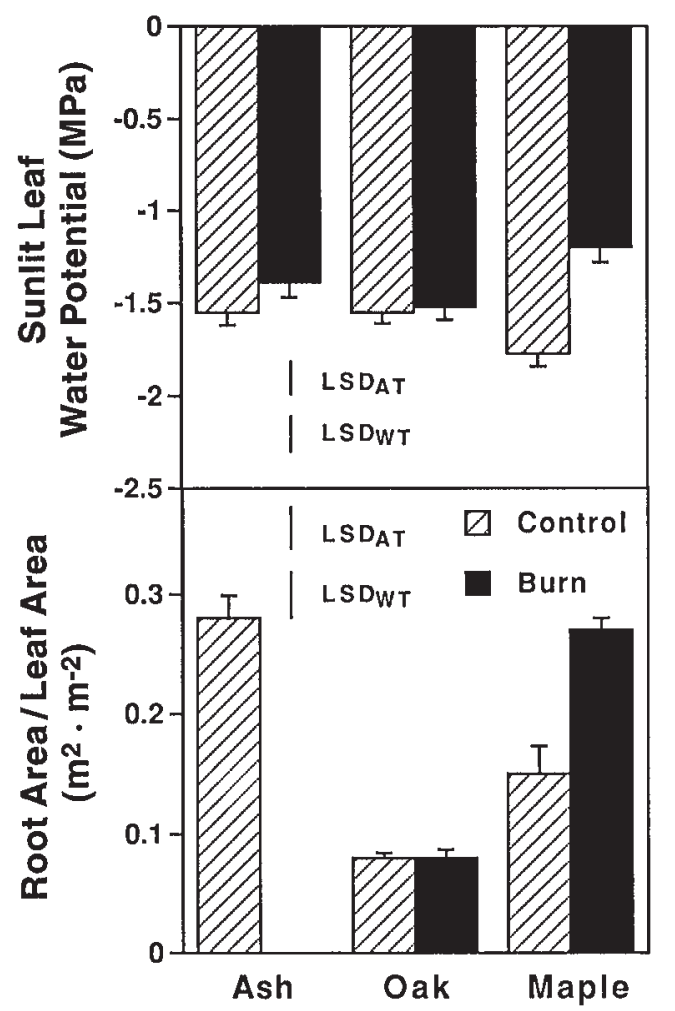

the comparison of years was confounded by differences in sampling period duration. In 1990 , soil $\mathrm{NO}_{3}{ }^{-}$concentrations tended to be higher on burn than control plots, but treatment differences were significant only on June 23.

\section{Discussion}

The physiological responses of woody vegetation to fire in a mesic hardwood forest were similar to those observed in other ecosystems (Oechel and Hastings 1983; Desouza et al. 1986; Reich et al. 1990; Fleck et al. 1995), as burning led to a stimulation of light-saturated photosynthesis in foliage of resprouting tree regeneration. The magnitude of this effect varied among hardwood species and corresponded closely with the extent of post-fire increases in stomatal conductance and $\mathrm{N}$ per unit leaf area. Maple exhibited the largest and most consistent changes in leaf properties, which in 1990 were accompanied by enhanced water availability to leaves and nearly a doubling in the ratio of root area to leaf area. These responses, which were either less pronounced or nonexistent in ash and oak, occurred in the absence of any clear treatment effect on soil moisture or $\mathrm{N}$ availability.

Based on these findings it appeared that leaf responses to fire were mediated primarily by a shift in the balance between the size of the root system and canopy. An increase in root/leaf ratio has been proposed as a possible factor contributing to the stimulation of leaf gas exchange in post-fire sprouts of chaparral (Oechel and Hastings 1983; DeSouza et al. 1986), Mediterranean shrubs (Fleck et al. 1995), and temperate deciduous trees (Reich et al. 1990). It may also underlie the enhanced gas exchange rates often observed in new or residual foliage following defoliation or coppicing (e.g., Heichel and Turner 1983; Tschaplinski and Blake 1989; Kruger and Reich 1993a, 1993b; Reich et al. 1993; Castell et al. 1994).

Among the hypothesized mechanisms linking gas exchange and root/leaf ratio, at least two appeared plausible in this study. Because the amount of leaf area supported by a given-sized root system decreased in maple after fire, $A_{\text {area }}$ and $g_{\mathrm{s}}$ may have responded positively to consequent increases in the supply of water, nutrients, and (or) root hormones per unit leaf area (Wareing et al. 1968; Meinzer and Grantz 1990; Meinzer et al. 1991). Alternatively (or additionally), the shift in maple root-leaf balance may have been associated with a decrease in source/sink ratio, which in turn led to a stimulation of photosynthetic capacity through an alleviation of end-product inhibition or other means (Neales and Incoll 1968; Tschaplinski and Blake 1989; Syvertsen 1994).

With the available evidence we could not fully resolve the causes underlying treatment effects on leaf gas exchange. If changes in foliar resource availability were responsible, it was unclear whether $\mathrm{N}$ nutrition or water played the most important role. As for N, light-saturated photosynthesis of sugar maple foliage has been shown to be positively correlated with LNA (Reich et al. 1991; Ellsworth and Reich 1992), and in this study the two parameters covaried fairly consistently. But there was also evidence that changes in leaf $\mathrm{N}$ status were not required to stimulate $A_{\text {area }}$ in maple. Such a response was induced by coppicing on control plots, and it was accompanied by an increase in $g_{\mathrm{s}}$ but not LNA. Furthermore, $A_{\text {area }}$ and $g_{\mathrm{s}}$ of post-fire maples were higher than those of noncoppiced controls at a given LNA.

The evidence against a pivotal role for $\mathrm{N}$ pointed instead to several alternatives, including the possibility that leaf function was modified by a change in source/sink ratio. This was consistent with observations that neither the relationship between $A_{\text {area }}$ and $g_{\mathrm{s}}$ nor the $\delta^{13} \mathrm{C}$ of maple stem tissue differed between burn and control plots, indicating that changes in $g_{\mathrm{s}}$ were closely coupled to those in photosynthetic capacity (Farquhar et al. 1989). It was also supported to some extent by trends in whole-plant biomass distribution (Kruger and Reich 1997b), as leaf weight ratio (LWR, g leaf.(g plant $)^{-1}$ ), a potential index of source-sink balance, was significantly lower on burn than control plots for maple in 1990. However, if LWR did reflect source/sink ratio, one might have expected that the increase in oak LWR after fire (Kruger and Reich 1997b) would result in a downward shift in oak $A_{\text {area }}$ on burn plots, which was not the case.

Given these considerations, we favored the alternative that both $g_{\mathrm{s}}$ and photosynthetic capacity increased in response to, or coincident with, an increase in the availability of water to foliage, and ultimately as a result of an increase in root/leaf ratio. A growing number of studies indicate that $g_{\mathrm{s}}$, and perhaps photosynthetic metabolism as well, may somehow be regulated, independently of bulk leaf water status, in accord 
Table 2. Relationships between net photosynthesis $\left(A_{\text {area }}, \mu \mathrm{mol} \cdot \mathrm{m}^{-2} \cdot \mathrm{s}^{-1}\right)$ and either the $\ln$ of stomatal conductance $\left(\ln g_{\mathrm{s}}\right.$ ) or N per unit leaf area (LNA, $\mathrm{g} \cdot \mathrm{m}^{-2}$ ) for ash, oak, and maple.

\begin{tabular}{|c|c|c|c|c|c|c|c|}
\hline \multirow[b]{2}{*}{ Species, treatment } & \multicolumn{7}{|c|}{ Regression parameters and coefficients } \\
\hline & $Y$ & $a$ & $b$ & $X$ & $n$ & $p$ & $r^{2}$ \\
\hline & \multicolumn{7}{|c|}{ Net photosynthesis versus the $\log _{\mathrm{e}}$ of stomatal conductance } \\
\hline Ash & $A_{\text {area }}$ & $-13.2 a$ & $3.84 a$ & $\ln g_{\mathrm{s}}$ & 58 & $<0.0001$ & 0.53 \\
\hline Oak & $A_{\text {area }}$ & $-12.5 b$ & $4.00 a$ & $\ln g_{\mathrm{s}}$ & 56 & $<0.0001$ & 0.60 \\
\hline \multirow[t]{2}{*}{ Maple } & $A_{\text {area }}$ & $-13.2 a$ & $3.70 a$ & $\ln g_{\mathrm{s}}$ & 63 & $<0.0001$ & 0.72 \\
\hline & \multicolumn{7}{|c|}{ Net photosynthesis versus leaf $\mathrm{N}$ per unit area } \\
\hline Ash & $A_{\text {area }}$ & $5.6 a$ & $3.38 a$ & LNA & 58 & 0.0002 & 0.23 \\
\hline Oak & $A_{\text {area }}$ & $5.0 a$ & $3.69 a$ & LNA & 56 & $<0.0001$ & 0.46 \\
\hline Maple, burn & $A_{\text {area }}$ & $4.6 a$ & $1.39 b$ & LNA & 33 & 0.02 & 0.21 \\
\hline Maple, control & $A_{\text {area }}$ & $4.0 b$ & $0.67 \mathrm{~b}$ & LNA & 30 & 0.35 & 0.04 \\
\hline
\end{tabular}

Note: Regression equations are in the form $Y=a+b X$, and for a given coefficient and general relationship, values without common letters are significantly different at $p \leq 0.05$. For all relationships, plot $\times$ species means from individual sampling dates in both years were used as experimental units. For the regression of $A_{\text {area }}$ against $\ln g_{\mathrm{s}}$, neither the slope nor the intercept differed significantly between treatments, and thus data from both treatments were pooled.

Table 3. Net $\mathrm{N}$ mineralization and concentrations of extractable $\mathrm{NO}_{3}{ }^{-}$and $\mathrm{NH}_{4}{ }^{+}$in soils on burn and control plots during 1989 and 1990.

\begin{tabular}{cllcrr}
\hline & $\begin{array}{c}\text { Measurement } \\
\text { period }\end{array}$ & Treatment & $\begin{array}{c}\text { Net N } \\
\text { mineralization } \\
\left(\mu \mathrm{g} \cdot \mathrm{g}^{-1} \cdot \mathrm{month}^{-1}\right)\end{array}$ & $\begin{array}{r}\text { Extractable } \\
{\left[\mathrm{NO}_{3}^{-}\right]} \\
\left(\mu \mathrm{g} \cdot \mathrm{g}^{-1}\right)\end{array}$ & $\begin{array}{r}\text { Extractable } \\
{\left[\mathrm{NH}_{4}^{+}\right]} \\
\left(\mu \mathrm{g} \cdot \mathrm{g}^{-1}\right)\end{array}$ \\
\hline 1989 & May 4- Nov. 15 & Control & $2.7(2.1)$ & $2.5(0.1)$ & $7.7(0.3)$ \\
& & Burn & $1.7(1.0)$ & $3.0(0.4)$ & $8.2(0.8)$ \\
1990 & Understory & $-1.2(0.4)$ & $2.2(0.6)$ & $11.2(1.0)$ \\
& May 1 - June 21 & Control & $7.9(2.1)$ & $3.1(0.7)$ & $3.4(0.3)$ \\
& & Burn & $8.8(0.5)$ & $3.4(0.3)$ & $3.5(0.5)$ \\
& June 23 - Aug. 14 & Control & $10.2(2.2)$ & $2.9(0.7)^{*}$ & $3.5(0.3)$ \\
& & Burn & $11.9(0.5)$ & $4.0(0.1)$ & $3.5(0.4)$ \\
& Oct. 1 - Nov. 1 & Control & $0.9(0.4)$ & $5.1(0.4)$ & $6.0(0.2)$ \\
& & Burn & $1.5(0.1)$ & $5.5(0.1)$ & $5.3(0.6)$ \\
\hline
\end{tabular}

Note: An asterisk indicates a significant difference $(p \leq 0.05)$ between treatment means for a particular variable within a given measurement period. Mineralization rates were measured during the indicated periods, whereas extractable $\left[\mathrm{NO}_{3}{ }^{-}\right]$and $\left[\mathrm{NH}_{4}{ }^{+}\right]$ were measured at the beginning of each period. Adjacent understories were sampled in 1989 but not in 1990.

with the hydraulic conductivity of the soil-leaf pathway (Teskey et al. 1983; Meinzer and Grantz 1990; Kruger and Reich 1993a; Yoder et al. 1994; Whitehead et al. 1996). The exact nature of this mechanism is unclear, as both hydraulic (Teskey et al. 1983; Malone 1993) and nonhydraulic signals (Meinzer et al. 1991; Tardieu and Davies 1993) may be involved. At least one root-derived hormone, abscisic acid, has been shown to affect both $g_{\mathrm{s}}$ and photosynthetic metabolism in a coordinated manner (Raschke and Hedrich 1985). Of course, a hormonal effect might have arisen, independent of any hydraulic mechanism, simply because of an increase in the amount of hormone supplied by a relatively large root system.

It was unclear why fire had a differential effect on root/leaf ratio among the three species in this study, but the large response in maple coincided with an overall lack of resprouting vigor after fire (Kruger and Reich 1997a, 1997b). Perhaps post-fire canopy development in maple was constrained by the number, spatial distribution, or structural characteristics (e.g., number of leaf primordia) of basal buds. It did not appear to be limited by $\mathrm{N}$ or carbohydrate reserves (Kruger and Reich 1997b). Species differences in phenology may have been important in this regard. Top kill has been shown to increase root/leaf ratio in oak only if the damage occurs when the shoot is actively growing (Kruger and Reich 1993b), and maple shoots were most active at the time of the burn in both years. However, Huddle and Pallardy (1996) found that maple seedlings resprouted much less frequently than oak seedlings when actively growing stems of both species were exposed to temperature regimens typifying conditions at the soil surface during a ground fire.

At various times during this study treatment differences in leaf function may have resulted in part from the delay in leaf phenology caused by fire. In the cases of ash and maple, gas exchange rates and $\mathrm{N}$ concentration of older foliage tended to decline steadily on control plots in late summer, and treatment differences in leaf properties were most obvious during that period. By example, a delay in phenology on burn plots appeared to underlie the treatment difference in $A_{\text {area }}$ and $g_{\mathrm{s}}$ for ash in 1989 (Fig. 1). Moreover, maple leaf vigor differed considerably between early- and late-season flushes on control plots in 1990, with the late flush resembling post-fire foliage in gas exchange and $\mathrm{N}$ status as well as the timing of senescence. Factors underlying maple leaf behavior on burn plots may have also contributed to the contrast between maple leaf 
cohorts on control plots. The redistribution of $\mathrm{N}$ or other nutrients from older senescing leaves, along with their steadily declining demand for root resources, may have afforded the late flush with ample nutrition, water, and (or) root metabolites.

This study is one of a growing number (e.g., Aston and Lawlor 1979; Küppers 1984; Meinzer and Grantz 1990; Kruger and Reich 1993a; Wan et al. 1993; Whitehead et al. 1996) providing evidence that leaf gas exchange may often be constrained by root/leaf ratio, which controls leaf access to water, nutrients, hormones, and other root metabolites. This tenet forms the basis for various models of leaf function (e.g., Givnish 1986), and such approaches could prove to be particularly useful in explaining or predicting vegetation responses to fire, herbivory, or other disturbances. Improved leaf photosynthesis may play a key role in the post-fire recovery of woody survivors (Kruger and Reich 1997b), and variation among species in leaf response could have important implications for post-fire competitive interactions and community dynamics (Kruger and Reich 1997a).

\section{Acknowledgments}

We are very grateful to Rachel and Don Jordan for letting us conduct this project in the Jordan Timberland, and for their continuing support of oak ecology research. Financial support was provided by the Elmer G. Biddick Foundation, The Nature Conservancy, The University of Wisconsin-Madison, and the USDA Competitive Grants Program (CRGO-USDA 9037290-5686). Carbon isotope analyses were conducted in the laboratory of Wallace Cleland (Department of Chemistry) at the University of Wisconsin-Madison. We also thank John Bliss, David Ellsworth, Ron Gropp, John Volin, Dirk Vanderklein, Mike Walters, and Beth Wertschnig for their assistance in various aspects of the study. We are particularly indebted to Brian Kloeppel for his invaluable help throughout the project.

\section{References}

Ahlgren, C.E. 1974. Effects of fires in temperate deciduous forests: north central United States. In Fire and ecosystems. Edited by T.T. Kozlowski and C.E. Ahlgren. Academic Press, New York. pp. 195-223.

Aston, M.I., and Lawlor, D.W. 1979. The relationship between transpiration, root water uptake, and leaf water potential. J. Exp. Bot. 30: $169-181$.

Bond, W.J., and van Wilgen, B.W. 1996. Fire and plants. Chapman and Hall, London, U.K.

Bunce, J.A., and Ward, D.A. 1985. Errors in differential infrared carbon dioxide analysis resulting from water vapor. Photosynth. Res. 6: 289-294.

Busch, D.E., and Smith, S.D. 1993. Effects of fire on water and salinity relations of riparian woody taxa. Oecologia, 94: 186-194.

Castell, C., Terradas, J., and Tenhunen, J.D. 1994. Water relations, gas exchange, and growth of resprouts and mature plant shoots of Arbutus unedo L. and Quercus ilex L. Oecologia, 98: 201-211.

DeSouza, J., Silka, P.A., and Davis, S.D. 1986. Comparative physiology of burned and unburned Rhus laurina after chaparral wildfire. Oecologia, 71: 63-68.

Ellsworth, D.S., and Reich, P.B. 1992. Leaf mass per area, nitrogen content and photosynthetic carbon gain in Acer saccharum seedlings in contrasting light environments. Funct. Ecol. 6: 423-435.
Eno, C.F. 1960. Nitrate production in the field by incubating the soil in polyethylene bags. Soil Sci. Soc. Am. Proc. 24: 277-279.

Farquhar, G.D., Ehleringer, J.R., and Hubick, K.T. 1989. Carbon isotope discrimination and photosynthesis. Annu. Rev. Plant Physiol. Plant Mol. Biol. 40: 503-537.

Fleck, I., Diaz, C., Pascual, M., and Iniguez, F.J. 1995. Ecophysiological differences between first-year resprouts after wildfire and unburned vegetation of Arbutus unedo and Coriaria myrtifolia. Acta Oecol. 16: 55-69.

Givnish, T.J. 1986. Optimal stomatal conductance, allocation of energy between leaves and roots, and the marginal cost of transpiration. In On the economy of plant form and function. Edited by T.J. Givnish. Cambridge University Press, Cambridge, U.K. pp. 171-213.

Gower, S.T., and Son, Y. 1992. Differences in soil and leaf litterfall nitrogen dynamics for five forest plantations. Soil Sci. Soc. Am. J. 56: 1959-1966.

Heichel, G.H., and Turner, N.C. 1983. $\mathrm{CO}_{2}$ assimilation of primary and regrowth foliage of red maple (Acer rubrum L.) and red oak (Quercus rubra L.): response to defoliation. Oecologia, 57: 14-19.

Huddle, J.A., and Pallardy, S.G. 1996. Effects of soil and stem base heating on survival, resprouting and gas exchange of Acer and Quercus seedlings. Tree Physiol. 16: 583-589.

Kruger, E.L., and Reich, P.B. 1993a. Coppicing alters ecophysiology of Quercus rubra saplings in Wisconsin forest openings. Physiol. Plant. 89: 741-750.

Kruger, E.L., and Reich, P.B. 1993b. Coppicing affects growth, root:shoot relations and ecophysiology of potted Quercus rubra seedlings. Physiol. Plant. 89: 751-760.

Kruger, E.L., and Reich, P.B. 1997a. Responses of hardwood regeneration to fire in mesic forest openings. I. Post-fire community dynamics. Can. J. For. Res. 27: 1822-1831.

Kruger, E.L., and Reich, P.B. 1997b. Responses of hardwood regeneration to fire in mesic forest openings. III. Whole-plant growth, biomass distribution, and nitrogen and carbohydrate relations. Can. J. For. Res. 27: 1841-1850.

Küppers, M. 1984. Carbon relations and competition between woody species in a central European hedgerow. II. Stomatal responses, water use, and hydraulic conductivity in the root-leaf pathway. Oecologia, 64: 344-354.

Lachat Inc. 1986. Ammonia in $2 \mathrm{M} \mathrm{KCl}$ soil extracts. Lachat Inc., Mequon, Wis. Quikchem Method 12-107-06-2-A.

Lachat Inc. 1987. Nitrate and nitrite in $2 \mathrm{M} \mathrm{KCl}$ soil extracts. Lachat Inc., Mequon, WI. Quikchem Method 12-107-04-1-A.

Malone, M. 1993. Hydraulic signals. Philos. Trans. R. Soc. Lond. B Biol. Sci. 341: 33-39.

Meinzer, F.C., and Grantz, D.A. 1990. Stomatal and hydraulic conductance in growing sugarcane: stomatal adjustment to water transport capacity. Plant Cell Environ. 13: 383-388.

Meinzer, F.C., Grantz, D.A., and Smit, B. 1991. Root signals mediate coordination of stomatal and hydraulic conductance in growing sugarcane. Aust. J. Plant Physiol. 18: 329-338.

Milliken, G.A., and Johnson, D.E. 1989. Analysis of messy data. Chapman and Hall, New York.

Neales, T.F., and Incoll, L.D. 1968. The control of leaf photosynthesis rate by the level of assimilate concentration in the leaf: a review of the hypothesis. Bot. Rev. 34: 107-125.

Oechel, W.C., and Hastings, S.J. 1983. The effects of fire on photosynthesis of chaparral resprouts: Mediterranean-type ecosystems. Edited by F.J. Kruger, D.T. Mitchell, and J.U.M. Jarvis. Ecol. Stud. 43: 274-285.

Perala, D.A. 1974. Prescribed burning in an aspen-mixed hardwood forest. Can. J. For. Res. 4: 222-228.

Raschke, K., and Hedrich, R. 1985. Simultaneous and independent effects of abscisic acid on stomata and the photosynthetic apparatus in whole leaves. Planta, 163: 105-118. 
Reich, P.B., Abrams, M.D, Ellsworth, D.S, Kruger, E.L., and Tabone, T.J. 1990. Eco-physiological and community responses of woody species to fire in a Wisconsin oak forest. Ecology, 71: 2179-2190.

Reich, P.B., Walters, M.B., and Ellsworth, D.S. 1991. Leaf age and season influence the relationships between leaf nitrogen, leaf mass per area, and photosynthesis in maple and oak trees. Plant Cell Environ. 14: 251-259.

Reich, P.B., Walters, M.B., Krause, S.D., Vanderklein, D., Raffa, K.F., and Tabone, T.J. 1993. Defoliation affects growth and physiological response of red pine seedlings and trees: influence of timing and intensity of stress. Trees, 7: 67-77.

Ritchie, G.A., and Hinckley, T.M. 1975. The pressure chamber as an instrument of ecological research. Adv. Ecol. Res. 9: 165-254.

SAS Institute Inc. 1988. SAS/STAT user's guide: release 6.03 edition, SAS Institute Inc., Cary, N.C.

Schulte, E.E., Peters, J.B., and Hodgson, P.R. 1987. Wisconsin procedures for soil testing, plant analysis and feed and forage analysis. Soil Fertility Series. No. 6. Department of Soil Science, University of Wisconsin-Extension, Madison.

Syvertsen, J.P. 1994. Partial shoot removal increases net $\mathrm{CO}_{2}$ assimilation and alters water relations of Citrus seedlings. Tree Physiol. 14: 497-508.

Tardieu, F., and Davies, W.J. 1993. Integration of hydraulic and chemical signalling in the control of stomatal conductance and water status of droughted plants. Plant Cell Environ. 16: 341-349.

Teskey, R.O., Hinckley, T.M., and Grier, C.C. 1983. Effect of interruption of flow path on stomatal conductance of Abies amabilis. J. Exp. Bot. 34: 1251-1259.
Tschaplinski, T.J., and Blake, T.J. 1989. Photosynthetic reinvigoration of leaves following shoot decapitation and accelerated growth of coppice shoots. Physiol. Plant. 75: 157-165.

United States Department of Commerce. 1989. Climatological data, Wisconsin. Bull. 94, National Oceanic and Atmospheric Administration, Asheville, N.C.

United States Department of Commerce. 1990. Climatological data, Wisconsin. Bull. 95, National Oceanic and Atmospheric Administration, Asheville, N.C.

von Caemmerer, S., and Farquhar, G.D. 1981. Some relationships between the biochemistry of photosynthesis and the gas exchange of leaves. Planta, 153: 376-387.

Wan, C., Sosebee, R.E., and McMichael, B.L. 1993. Growth, photosynthesis, and stomatal conductance in Gutierrezia sarothrae associated with hydraulic conductance and soil water extraction by deep roots. Int. J. Plant Sci. 154: 144-151.

Wareing, P.F., Khalifa, M.M., and Treharne, K.J. 1968. Rate-limiting processes in photosynthesis at saturating light intensities. Nature (London), 220: 453-457.

Whitehead, D., Livingston, N.J., Kelliher, F.M., Hogan, K.P., Pepin, S., McSeveny, T.M., and Byers, J.N. 1996. Response of transpiration and photosynthesis to a transient change in illuminated foliage area for a Pinus radiata D. Don tree. Plant Cell Environ. 19: 949-957.

Yoder, B.J., Ryan, M.G., Waring, R.H., Schoettle, A.W., and Kaufman, M.R. 1994. Evidence of reduced photosynthetic rates in old trees. For. Sci. 40: 513-527. 